\title{
The Western Harvester Ants: Their Density and Hill Size in Relation to Herbaceous Productivity and Big Sagebrush Cover
}

\author{
FORREST A. SNEVA
}

\begin{abstract}
Ant colony density decreased but the denuded disc area increased as big sagebrush crown cover increased and as herbaceous productivity decreased.
\end{abstract}

The western harvester ants (Pogonomyrmex occidentalis Cresson and $P$. owyheei Cole) have been of interest since the colonization of the Western range. McCook (1879, $1882 \mathrm{a} \& \mathrm{~b}$, and 1883) made intensive and extensive studies of the harvester ant as far west as Reno, Nevada. Biological and ecological studies were sporadic through the close of that century and the beginning of this century. Agricultural interest relating to their impact on crop production resulted in studies by Johnson et al. (1938), Costello (1944), Hull and Killough (1951), Gilbert (1960), Sharp and Barr (1960), and Wight and Nichols (1966). Control of these ants was first reported in 1942 by Fritz and Vickers, but widespread control studies were not conducted until the 1950's and those are documented by the works of Knowlton (1966) in Utah, Lavigne and Fisser (1966) in Wyoming, Race (1966) in New Mexico, and Crowell (1963) in Oregon. The association of ants with, and their impact on, grazed ranges has not been totally resolved by the studies reported. Rogers (1972) associated an increase in hill density with pastures heavily grazed but Kirkham and Fisser (1972) were unable to produce this result after 10 years of grazing with various levels of grazing intensity. They did show, however, that soil texture was the most important factor influencing ant distribution. Similarly, while some workers have estimated productive losses due to the denuded disc, Rogers (1972) and Wight and Nichols (1966) reported increased growth on the disc perimeter which partially or wholly compensate for production loss on the disc area.

This note presents information of effects of harvester ant activity that spans a 40-year period. It relates changes in ant hill density and disc area with other measured attributes of their environment.

\section{Study Site}

The Squaw Butte Experiment Station lies within the cold, high desert province of eastern Oregon. It is typical of an extensive region that also includes parts of Idaho, Nevada, and California. The study area lies at approximately $1,370 \mathrm{~m}$ elevation and receives an average of $30.5 \mathrm{~cm}$ of precipitation, annually.

The vegetation-soil complex of some of these sites has been described by Eckert (1957). These data are derived from sites classified by him as the Stipa thurberiana phase of Artemisia

The research is a cooperative investigation of the U.S. Dep. Agr., SEA, Agricultura Research, and the Oregon State Agr. Exp. Sta., Squaw Butte Experiment Station, Burns. Technical Paper 4659 of the Oregon State Agr. Exp. Sta.

The author is range scientist, U.S. Department of Agriculture, Science and Education Administration, Agricultural Research, Burns, Oregon 97720.

Manuscript received January 16, 1978.
tridentata/Agropyron spicatum habitat. Other important grass species are Sitanion hystrix (Nutt.) J.G. Smith, Poa secunda Presl., and Koeleria cristata (L.) Pers. In years of high precipitation and on disturbed areas Bromus tectorum L. is abundant. The dominant perennial forb is Phlox diffusa Benth.; Collinsia parviflora Dougl. ex Lindl. is the most abundant annual species.

Soils of this vegetative type are sandy loams overlying sandy-clayloams in the B horizon and are part of a gently sloping fan derived from alluvial materials of basaltic and rhyolitic origin. A cemented pan, found at depths of 50.8 to $140 \mathrm{~cm}$, restricts the growth of grass roots but is penetrated by shrubs.

\section{Procedure}

In 1962 and 1974, ant colony surveys took place within a fenceenclosed 16.2-ha range pasture that in 1952 had been treated with 2,4-D to control big sagebrush. Data in 1938 were obtained from surveys by Johnson et al. (1938) within a 64.8 -ha pasture within 0.8 $\mathrm{km}$ of the previously mentioned pasture.

Surveys in 1962 and 1974 consisted of 400 sample points on a $6.1-\mathrm{m}$ grid pattern. At each point the number of ant hills within a circular $37.2 \mathrm{~m}^{2}$ plot were tallied. Additionally, the longest diameter of the disc (denuded area) and the cross diameter at right angles to that axis at its midpoint for each hill were recorded. The mean of the two diameters was used to compute total disc area per hill and per sample $\left(A .=0.7854 d^{2}\right)$.

In 1938, all hills within the 64.8-ha pasture were located and tallied. Disc areas of 100 hills were estimated from several measurements per disc (Johnson et al. 1938).

Total herbaceous production by species on the 16.2-ha pasture was taken annually, after grass maturity, in the years 1950 through 1974. Yield was estimated from 60 random plots $\left(4.5 \mathrm{~m}^{2}\right)$ harvested at ground level. Sagebrush cover estimates on control plots of an associated study within the 16.2-ha pasture were taken in 1950, 1951, and 1952 (Hyder and Sneva 1956). In 1970, 1972, and 1974 brush cover intercept was read from randomly located $30.5-\mathrm{m}$ lines.

Herbage production and brush cover estimates were not measured by Johnson et al. in 1938. An estimate of herbage production was derived for the 64.8-ha pasture from the 1938 range inventory records on file at this station. An estimate of big sagebrush was developed from 1938 records of three, $6.1-\mathrm{m}^{2}$ permanent charted plots. Ten randomly placed lines per chart were read from which brush cover intercept was estimated.

\section{Results and Discussion}

Johnson et al. (1938) classified the ants in his study as $P$ occidentalis, but it is now recognized that $P$ occidentalis normally does not inhabit eastern Oregon. The species in their study was probably $P$. owyheei, (Cole 1968).

Brush cover data (Table 1) estimated from 1938 permanentchart records were derived from a rather small sample, but nevertheless were believed to be reliable. Tueller (1962) reinventoried all such permanent plots on the Squaw Butte Station in 1960 and found only a small change in brush cover since 1938. Brush cover in the 16.2-ha pasture in the early 1950's before brush control also averaged 20\%, (Hyder and Sneva 1956). 
Table 1. Summary for ant, herbage, brush, and precipitation statistics.

\begin{tabular}{llrrr}
\hline & & \multicolumn{3}{c}{ years } \\
\cline { 3 - 5 } & Measure & 1938 & 1962 & 1974 \\
\hline Big sagebrush cover & $(\%)$ & 20 & 5 & 14 \\
Herbaceous yield & $(\mathrm{kg} / \mathrm{ha})$ & 262 & 520 & 346 \\
Sept. - June precipitation & $(\mathrm{cm})$ & 29.7 & 19.1 & 23.2 \\
Crop-year yield index & $(\%)$ & 107 & 65 & 82 \\
No. Ant hill/ha & & 32.4 & 80.1 & 56.5 \\
Disc area & $\left(\mathrm{m}^{2} / \mathrm{hill}\right)$ & 9.3 & 0.9 & 1.5 \\
Disc area & $\left(\mathrm{m}^{2} / \mathrm{ha}\right)$ & 301.3 & 72.1 & 84.8 \\
Disc area & $(\%)$ & 3.0 & 0.7 & 0.8 \\
Yield loss (disc area) & $(\mathrm{kg} / \mathrm{ha})$ & 7.9 & 3.6 & 2.7 \\
Herbage available & $(\mathrm{kg} / \mathrm{hill})$ & 8.1 & 6.5 & 6.1 \\
Herbage available $^{2}$ & $(\mathrm{~kg} / \mathrm{hill})$ & 7.6 & 10.0 & 7.5 \\
& & & & \\
\hline
\end{tabular}

Estimated from $\mathrm{y}=1.11 \times-10.6$ where $\mathrm{x}$ is Sept. - June precipitation/long term cropyear median amount $(27.9 \mathrm{~cm}) \times 100$. Sneva and Hyder $(1962)$

" Adjusted by the crop-year yield index

Brush Control in 1952 effectively killed most all sagebrush present. Plant mortality in 1953 was estimated to be in excess of $95 \%$

The 1938 herbaceous yield estimate of $262 \mathrm{~kg} /$ ha was derived from the 1938 range survey of four, 810-ha pastures on the Squaw Butte Station. The estimate is believed to be a fair approximation of the yield in this smaller but similarly vegetated pasture.

Herbage yield was mainly that of perennial grasses, with bluebunch wheatgrass (Agropyron spicatum) the primary contributor to yield. In the years 1962 and 1974 following brush control in 1952, downy bromegrass (Bromus tectorum) contributed 28 and $9 \%$ of the total yield, respectively. Annual and perennial broad leaf plants seldom exceeded $10 \%$ of the total yield weight.

Ant hill density ranged from 32.4 to 80.1 hills per hectare, the greater number per hectare being associated with the least amount of brush cover and the highest herbaceous productivity (Table 1). The amount of disc area around each hill was smallest in 1962 (averaging $0.9 \mathrm{~m}^{2}$ per hill); and, despite the greater number of colonies per hectare, the total amount of disc area per hectare was the least $\left(72.1 \mathrm{~m}^{2}\right)$

The fewer number of hills per hectare but much greater area of the disc denuded in 1938 as compared with that in 1962 and 1974 may be due to location. The 64.8-ha pasture, although less than 0.8 kilometer from the later study area, was further out into the valley area. Situated thusly, the soils may be slightly shallower due to less deposition over the years. A shallower soil depth may cause the colony to expand itself greater in the horizontal plane. Also, in 1938, the area was in the process of recovering from the drought years and the measurements in 1938 may have been a reflection of conditions favorable or unfavorable to the ant in the preceeding years.

Ant hill density declined from 1962 to 1974 and this was associated with about $9 \%$ increase in brush cover. As the sagebrush returned, herbaceous production decreased from 755 $\mathrm{kg} / \mathrm{ha}$ in years $1958-1963$ to $346 \mathrm{~kg} / \mathrm{ha}$ in the years 1971 to 1973. Grazing occurred in this pasture in all years following grass maturity, but the stocking rate was low with utilization guidelines allowing $336 \mathrm{~kg} / \mathrm{ha}$ of herbage remaining or $50 \%$ utilization of the perennial grasses, whichever was the least in all years. It is unlikely that grazing contributed greatly to the increase of brush under those conditions.

Loss of herbaceous production based on the denuded disc area ranged from 1 to $3 \%$. These are similar to percentage losses reported by other investigators. The quantitative yield loss in each of those years was 7.9, 3.6, and $2.7 \mathrm{~kg} / \mathrm{ha}$ for 1938,1962 , and 1974, respectively. Willard and Crowell (1965) reported the foraging activity of $P$. owhyeei to be greatest within $15.2 \mathrm{~m}$ of the mound and that the harvesting activity was directed primarily toward seeds of annual species. Thus, at the densities measured in this study, the associated small loss of production and the assumption that the seeds of annual species are being harvested, the total return from ant control does not, in the author's opinion, justify the expense.

Ants are primarily seed gatherers; thus, an estimate of available herbaceous productivity per mound may not be realistic. Willard and Crowell (1965) concluded that where mound density ranged from 49 to 74 per hectare, the entire area was being foraged by the ant. Densities in the latter study were in this range. It is interesting to note that despite wide fluctuations in mound density and disc area, the quantity of herbaceous material available per hill remained fairly constant. The amounts varied from 6.1 to $8.1 \mathrm{~kg} / \mathrm{hill}$; and when herbage production was adjusted for year influence, it averaged 8.4 $\mathrm{kg} / \mathrm{hill}$.

\section{Literature Cited}

Cole, Arthur C. 1968. Pogonomyrmex Harvester Ants: A Study of the Genus in North America. Univ. of Tennessee Press. Knoxville.

Costello, David F. 1944. Natural revegetation of abandoned plowed land in the Mixed Prairie association of northeastern Colorado. Ecology 25:312-26.

Crowell, H.H. 1963. Control of the Western harvester ants, Pogonomyrmex occidentalis with poisoned baits. J. Econ. Entomol. 56:295-98.

Fritz, R.F., and W.A. Vickers. 1942. Damage to highways by the moundbuilding prairie ant. J. Econ. Entomol. 35: 725-727.

Gilbert, Harold. 1960. Sheridan man conducts survey of ant hills on Wyoming ranges. Wyoming Stockman-Farmer 66:29-63.

Hull, A.C. Jr., and J.R. Killough. 1951. Ants are consuming Big Horn Basin ranges. Western Farm Life, Annu. Livestock Rev. 53:70.

Hyder, D.N., and F.A. Sneva. 1956. Herbage response to sagebrush spraying. J. Range Manage. 9:34-38.

Johnson, et al. 1938. The influence of the harvester ant (Pogomyrmex occidentalis Cress), upon range vegetation. Unpubl. Rep. Squaw Butte Oregon Agr. Exp. Sta. 12 p.

Kirkham, D.R., and H.G. Fisser. 1972. Rangeland relations and harvester ants in north-central Wyoming. J. Range Manage. 25:55-60.

Knowlton, George F. 1966. Western harvester ants. A range and farm problem. Utah State Ext. Serv. Entomol. Mimeo Ser. 111, 1 p.

Lavigne, R.J. and H.G. Fisser. 1966. Controlling Western harvester ants. Mountain States Reg. Publ. 3, 4 p.

McCook, Henry C. 1879. Remarks on Pogonomyrmex occidentalis p. 22, In: Proceedings of Monthly Meetings of the Entomological Section on the Academy of Natural Sciences, Philadelphia. Trans. Amer. Entomol. Soc. 7, XLIV and $340 \mathrm{p}$.

McCook, H.C. 1882a. The Honey Ants of the Garden of the Gods, and the Occident Ants of the American Plains. Lippincott and Co., Philadelphia. 188 p.

McCook, H.C. 1882b. Ants as beneficial insecticides. Proc. Acad. Natural Sci., Philadelphia. 188:263-71.

McCook, H.C. 1883. The occident ant of dakota. Proc. Acad. Natural Sci., Philadelphia. 188:263-71.

Race, S.R. 1966. Control of Westem harvester ants on rangeland. N. Mex. Agr. Exp. Sta. Bull. 502.

Rogers, Lee E. 1972. The ecological effects of the Western harvester ant (Pogonomyrmex occidentalis) in the shortgrass plains ecosystem. Unpubl. PhD. Thesis. University of Wyoming, Laramie. $114 \mathrm{p}$.

Sharp, L.A., and W.F. Barr. 1960. Preliminary investigations of harvester ants on southern Idaho rangelands. J. Range Manage. 13:131-34.

Sneva, Forrest A., and D.N. Hyder. 1962. Forecasting range herbage production in eastern Oregon. Oregon State Univ. Agr. Exp. Sta. Bull. 588. 11 p.

Tueller, Paul T. 1962. Plant succession on two Artemisia habitat types in southeastern Oregon. PhD. Thesis, Oregon State Univ., Corvallis.

Willard, J.R., and H.H. Crowell. 1965. Biological activities of the harvester ant. $P$. owyheei, in central Oregon. J. Ex. Entomol. 58:484-489.

Wight, J. Ross, and James T. Nichols. 1966. Effects of harvester ants on production of saltbush community. J. Range Manage. 19:68-71. 